\title{
Effects of black cohosh on estrogen biosynthesis in normal breast tissue in vitro
}

\author{
Petra Stute $^{\mathrm{a}, *}$, Thomas Nisslein ${ }^{\mathrm{b}}$, Martin Götte ${ }^{\mathrm{a}}$, Axel Kamischke ${ }^{\mathrm{c}}$, \\ Ludwig Kiesel $^{\mathrm{a}}$, Walter Klockenbusch ${ }^{\mathrm{a}}$ \\ ${ }^{a}$ Department of Obstetrics and Gynecology, University Clinic of Muenster, 48149 Muenster, Germany \\ ${ }^{\mathrm{b}}$ Schaper \& Brümmer GmbH \& Co. KG, 38259 Salzgitter, Germany \\ ${ }^{c}$ Department of Obstetrics and Gynecology, St. Barbara Clinic, Hamm, Germany
}

Received 21 November 2006; received in revised form 16 April 2007; accepted 20 April 2007

\begin{abstract}
Objectives: To investigate the effect of black cohosh on the estrogen biosynthesis in the breast in vitro.

Methods: Steroid sulfatase (STS) activity was studied in normal breast tissue obtained from pre- and postmenopausal women undergoing reduction mammoplasty. STS protein expression was studied by immunohistochemistry and western blotting. Breast tissue was incubated in vitro without or with black cohosh (iCR) at concentrations ranging from $0.1 \mathrm{mg} / \mathrm{ml}$ to $1 \mathrm{ng} / \mathrm{ml}$. STS activity was evaluated by incubating homogenized breast tissue with $\left[{ }^{3} \mathrm{H}\right]$-estrone sulfate, separating the formed products, estrone $\left(\mathrm{E}_{1}\right)$ and estradiol $\left(\mathrm{E}_{2}\right)$, by thin layer chromatography and measuring the amounts of $\mathrm{E}_{1}$ and $\mathrm{E}_{2}$ by scintillation counting.

Results: STS protein expression and enzymatic activity were detected in all specimens investigated. In all groups, significantly more $E_{1}$ than $E_{2}$ was produced. Local estrogen formation was decreased in premenopausal breast tissue by treatment with iCR at $0.1 \mathrm{mg} / \mathrm{ml}(p \leq 0.05)$.

Conclusions: iCR decreases local estrogen formation in normal human breast tissue in vitro. This may contribute to the lack of hormonal effects of black cohosh in breast tissue observed in previous studies.

(C) 2007 Elsevier Ireland Ltd. All rights reserved.
\end{abstract}

Keywords: Breast; Black cohosh; Actaea racemosa; Cimicifuga racemosa; Sulfatase activity

\section{Introduction}

Postmenopausal hormone therapy (HT) has been seen as a specific treatment for climacteric symptoms

\footnotetext{
* Corresponding author. Tel.: +49 25183 48202; fax: +492518348267.

E-mail addresses: stutepe@mednet.uni-muenster.de, stutepe@web.de (P. Stute).
}

in the short term and as a prevention of chronic diseases in the long term [1-3]. However, several clinical trials have indicated an increased risk of breast cancer (BC) associated with HT [4-8]. In recent years, extracts of the rhizome of black cohosh (Actaea, syn. Cimicifuga racemosa) (CR) have been recognized as a rational choice for treatment and prevention of menopausal disorder $[9,10]$. So far, in vitro and in vivo studies 
suggest CR to be safe for the breast [11-16]. However, the precise mode of action of CR is not yet fully understood. According to the concept of intracrinology [17] suggesting that inactive hormones released by hormone-producing organs are transported via blood vessels to their target tissues where enzymes secure their conversion into active hormones, the amount of steroids locally available is more important than their serum concentration. The most biologically active estrogen in breast tissue is $17 \beta$-estradiol $\left(\mathrm{E}_{2}\right)$. Breast tissue and mammary cancer cells have been shown to possess the enzymatic systems necessary for the intratumoral biosynthesis of estrogens from precursor molecules circulating in plasma. Three main enzymes are important in this process: aromatase, which converts androgens to estrogens [18-20], $\mathrm{E}_{1} \mathrm{~S}$-sulfatase (STS) which hydrolizes $\mathrm{E}_{1} \mathrm{~S}$ to $\mathrm{E}_{1}$ [20-28], and 17 $\beta$ hydroxysteroid dehydrogenase type 1 (17ßHSD-1) which reduces $E_{1}$ to $E_{2}$ [29-32]. The activity of STS in breast tumors has been shown to be 10-500-fold higher than aromatase activity [33-35]. In BC, STS mRNA has been shown to be an independent prognostic indicator in predicting shorter relapse free survival [36] and to correlate positively with tumor size and lymph node metastasis [37]. Thus, STS seems to play a crucial role in local biosynthesis of estrogens in breast (cancer) tissue. Estradiol and various progestogens have been shown to influence STS in BC cells in vitro [38-44]. In vitro, the effect of steroids on local estrogen formation in normal and malignant breast cells is rather due to changes in STS activity than in its mRNA and protein levels [45]. We recently demonstrated that longterm HT alters local estrogen formation in breast tissue of postmenopausal cynomolgus monkeys (Macaca fascicularis) and women depending on breast tissue composition [46,47].

The aim of this study was to investigate the effect of an isopropanolic-aqueous $(40 \%, \mathrm{v} / \mathrm{v})$ extract of CR (iCR) on estrogen biosynthesis in breast tissue in vitro.

\section{Methods}

\subsection{Chemicals, reagents, and treatment}

The iCR (B. Nr. 010720) was provided by Schaper \& Brümmer GmbH \& Co.KG. Salzgitter, Germany.
The concentration of the extract was $100 \mathrm{mg} / \mathrm{ml}$ in relation to the dry residue. Alcohol concentration was $40 \%(\mathrm{v} / \mathrm{v})$. The final concentration of isopropanol in tissue homogenates during iCR treatment did not exceed $0.5 \%(\mathrm{v} / \mathrm{v})$. The same concentration of isopropanol was present in the control samples. Breast tissue homogenates were incubated without and with iCR at a concentration range from $10 \mathrm{mg} / \mathrm{ml}$ to $0.1 \mu \mathrm{g} / \mathrm{ml}$ leading to a final concentration range in the homogenate from $0.1 \mathrm{mg} / \mathrm{ml}$ to $1 \mathrm{ng} / \mathrm{ml}$, respectively. The radioactive labeled steroid $\left[{ }^{3} \mathrm{H}\right]-\mathrm{E}_{1} \mathrm{~S}$ (specific activity $57.3 \mathrm{Ci} / \mathrm{mmol}$ ), was purchased from Perkin Elmer Life and Analytical Sciences (549 Albany Street, Boston, MA, USA). Unlabeled $\mathrm{E}_{2}$ and $\mathrm{E}_{1}$ were obtained from Sigma. Unless stated otherwise, all chemicals were from Sigma-Aldrich (Deisenhofen, Germany).

\subsection{Subjects}

$\mathrm{E}_{1} \mathrm{~S}$ metabolism in normal breast tissue was studied in five post- and five premenopausal women undergoing reduction mammoplasty (Department of Plastic Surgery, Clinic Centrum Hohenzollernring, Muenster, Germany, Department of Gynecology and Obstetrics, St. Barbara Clinic, Hamm, Germany, and Department of Obstetrics and Gynecology, University Clinic of Muenster, Germany). The postmenopausal women's age was in the range from 48 to 70 years (mean $56 \pm 7.7$ years), and the premenopausal women's age in the range from 31 to 57 years (mean $43 \pm 9$ years; $p=0.05$ ). None of the women received hormonal treatment prior to breast surgery. Immediately following surgical removal, the tissue samples were shock frozen in liquid nitrogen and stored at $-70^{\circ} \mathrm{C}$ until thin layer chromatography for enzyme activity and western blotting for protein quantification were performed. Since one postmenopausal woman was extremely overweight (body mass index (BMI) 50) she was excluded from the subset of postmenopausal women when STS activity was evaluated. In addition, normal breast tissue obtained from another subset of women $(n=5)$ undergoing breast reduction mammoplasty (Department of Plastic Surgery, Fachklinik Hornheide, Germany) was immediately fixed in $10 \%$ neutral phosphate-buffered formalin for $\mathrm{H} \& \mathrm{E}$ staining and immunohistochemistry. Histological evaluation was performed by a board-specified pathologist (G. Edel, M.D., Ph.D., 
Institute of Pathology at the Franziskus Hospital in Muenster, Germany, Institute of Pathology Diebold, Niemann \& Schönfeld, Hamm, Germany). The breast tissue examined did not contain any malignant lesions.

Women gave written informed consent to their breast tissue being analyzed in addition to established pathological analysis.

\subsection{Immunohistochemistry}

Normal breast tissue obtained from a reduction mammoplasty of a 49-year-old healthy woman was formalin-fixed and paraffin-embedded using standard techniques. Consecutive sections of $2-3 \mu \mathrm{m}$ were cut from the paraffin blocks, dewaxed and re-hydrated. Antigen retrieval was performed by hot water steaming in citrate buffer ( $\mathrm{pH} \mathrm{6;} 30 \mathrm{~min})$. Following a blocking step with Aurion BSAc solution (DAKO, Glostrup, Denmark) for $30 \mathrm{~min}$, sections were incubated with a monospecific rabbit-anti human STS-antiserum [48], diluted 1:1000 in phosphate-buffered saline (PBS) containing $1 \%$ bovine serum albumine (BSA), or a control rabbit serum overnight at $4{ }^{\circ} \mathrm{C}$. Endogenous peroxidase activity was quenched with methanol $/ 0.6 \% \mathrm{H}_{2} \mathrm{O}_{2}$, followed by three washes with PBS. STS was detected using the DAKO cytomation rabbit-EnVision plushorseradish peroxidase (HRP) system and the AEC substrate (DAKO), followed by counterstaining with Mayer's Hemalum (Merck, Darmstadt, Germany). Sections were observed and documented using a Zeiss Axiovert 100 microscope equipped with an Axiophot Mrc camera.

\subsection{Western blotting}

For Western blotting, breast tissue extracts of five pre- and five postmenopausal women were diluted with SDS-sample buffer to a protein concentration of $1 \mu \mathrm{g} / \mu \mathrm{l}$. Twenty microliters of sample/lane were subjected to electrophoresis on $12 \%$ SDS-polyacrylamide gels and electro-transferred to nitrocellulose membranes as previously described [50]. Subsequently, the membranes were blocked with $5 \%$ non-fat dry milk in TBS containing $1 \%(\mathrm{v} / \mathrm{v})$ Tween 20 for $1 \mathrm{~h}$ at room temperature, washed $3 \times 5 \mathrm{~min}$ with TBS and incubated with anti-STS-antiserum [48] diluted 1:1500 in TBS containing 5\% BSA and $1 \%(\mathrm{v} / \mathrm{v})$ Tween at $4{ }^{\circ} \mathrm{C}$ for $16 \mathrm{~h}$. The membrane was washed $3 \times 5$ min with TBS (1\% Tween) and incubated with a peroxidaseconjugated goat-anti rabbit IgG antibody (Calbiochem, Nottingham, UK) diluted 1:2000 in TBS containing $5 \%$ BSA and $1 \%(\mathrm{v} / \mathrm{v})$ Tween at room temperature for $1 \mathrm{~h}$. The blot was washed $3 \times 5 \mathrm{~min}$ with TBS ( $1 \%$ Tween), followed by an enhanced chemoluminescence reaction (Super Signal, Pierce, Rockford, MA) and exposition to ECL-hyperfilm (Amersham, Braunschweig, Germany). To normalize for a loading control, blot membranes were stripped with $0.2 \mathrm{M}$ glycine, $\mathrm{pH} 2.5$ [50] and reprobed as described above, using a monoclonal mouse-anti tubulin primary antibody (Sigma-Aldrich, dilution 1:4000) and HRPconjugated goat-anti-mouse IgG secondary antibodies (Calbiochem, dilution 1:10,000), respectively. Scanned images of the exposed films were analyzed densiometrically using the NIH Image J software (NIH, Bethesda, USA), normalizing STS expression to tubulin content.

\section{5. $E_{1} S$-sulfatase (STS) activity assay}

STS activity was measured as described previously $[45,46]$. In brief, breast tissue $(150 \mathrm{mg})$ was finely minced with scissors and homogenized on ice, in $2 \mathrm{ml} 0.06 \mathrm{M}$ Tris-HCl-buffer $\mathrm{pH} 7.0$ (assay buffer throughout the entire procedure) for approximately $1 \mathrm{~min}$ at maximum speed using a Polytron homogenizer. All incubations were carried out in duplicate. The incubation mixtures consisted of $200 \mu l$ homogenate, 19.39 pmole $\left[{ }^{3} \mathrm{H}\right]-\mathrm{E}_{1} \mathrm{~S}$ in $100 \mu \mathrm{l}$ of buffer, and $100 \mu \mathrm{g}$ of NADH and NADPH in $100 \mu l$ of buffer (total incubation volume $400 \mu \mathrm{l}$ ). Simultaneous background incubations using buffer instead of tissue homogenate were performed in order to correct for non-enzymatic transformation of the substrate. After 15 and 45 min of incubation in air at $37^{\circ} \mathrm{C}$ in a water bath, $200 \mu \mathrm{g}$ of non-radioactive $\mathrm{E}_{1}$ and $17 \beta-\mathrm{E}_{2}$ were added in $100 \mu \mathrm{l}$ of ethanol together with $0.5 \mathrm{ml}$ of $0.5 \mathrm{M}$ sodium phosphate buffer, $\mathrm{pH}$ 7.0. The unconjugated steroids were extracted with $2.0 \mathrm{ml}$ toluene. After inverting the tubes 100 times they were centrifuged at $1500 \times g$ for $10 \mathrm{~min}$. The lower aqueous phase was frozen in liquid nitrogen. Hundred microliters of the upper toluene phase was removed and added to $100 \mu \mathrm{l}$ of buffer and $3.0 \mathrm{ml}$ of scintillation fluid to determine total hydrolysis. The remaining toluene phase was evaporated to dryness in nitrogen atmosphere and dissolved in $100 \mu \mathrm{l}$ 
Folch-Solution (2:1 chloroform:methanol). Thin layer chromatography (TLC) on Alugram Sil G/UV 254 (Roth; Macherey-Nagel Düren, Germany) was performed using $13 \%$ ethanol in toluene as solvent. After visualization in $254 \mathrm{~nm}$ UV light, the zones in the plate corresponding to the estrogens as well as the non-fluorescent zones were cut apart and separately eluted with $3 \mathrm{ml}$ ethanol and $6 \mathrm{ml}$ scintillation fluid. Aliquots were taken from each fraction from the TLC plate for counting of the $\left[{ }^{3} \mathrm{H}\right]$ activity. A Wallac 1409 ( $\beta$-Counter) scintillation spectrometer was used for the radioactivity measurements and Riafluor (New England Nuclear Corporation, Boston, MA, USA) was used as scintillation fluid. The enzyme activity was expressed as the amount of unconjugated estrogen $\left(E_{1}+E_{2}\right)$ formed per minute and per milligram of protein. The total protein was determined by the method of Bradford [49].
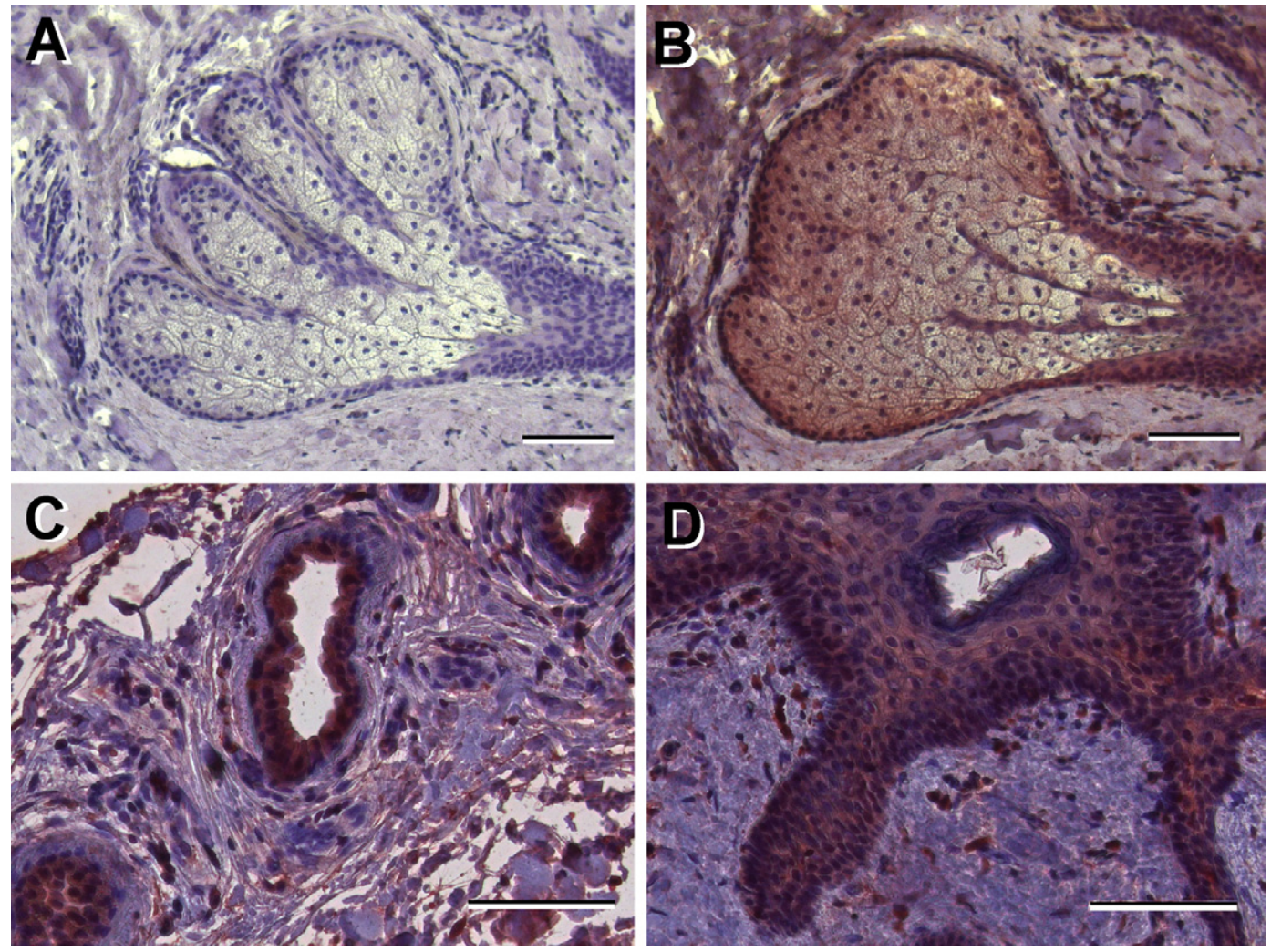

Fig. 1. Immunolocalization of STS in normal human breast tissue. Paraffin sections of normal breast tissue were immunostained with a monospecific antiserum against STS [48] (B-D), or a preimmune rabbit control antiserum (A). STS staining was predominantly found in epithelial cells. Bar $=50 \mu \mathrm{m}$.

\subsection{Statistical methods}

Results were expressed as the mean \pm standard error of the mean (S.E.M.). Statistical comparisons were made using the student's two-tailed test. A $p$ value $<0.05$ was considered to be significant. All treatment experiments were repeated at least four times. Negative STS activity values were set to zero and repeated measures were aggregated by calculating the mean.

\section{Results}

\subsection{Subjects' characteristics}

There were no significant group differences regarding age, BMI, number of pregnancies, deliveries, and 
miscarriages. Mean BMI was within the overweight range (postmenopausal women: $30 \pm 11 \mathrm{~kg} / \mathrm{m}^{2}$, and premenopausal women: $26 \pm 4 \mathrm{~kg} / \mathrm{m}^{2}$, respectively; $p=0.53$ ). Hysterectomy without ovarectomy had been performed in two of the five post-, and one of the five premenopausal women, respectively. None of the postmenopausal but two of the premenopausal women were current smoker. The family history (first and second degree) referring to breast cancer was negative for both groups. Breast cancer had occurred earlier in the mammary gland which was now subject of reduction mammoplasty in three of the five postmenopausal women. In the premenopausal subset one in five women had been treated for contralateral breast cancer prior to reduction mammoplasty. Reduction mammoplasty for cosmetic reason only was performed in one in five postand four in five premenopausal women. Prior to breast surgery a mammogram was performed to prove lack of suspicious lesions.

\section{2. $E_{1} S$-sulfatase (STS) protein expression and localization}

To confirm the expression of STS in normal breast tissue, we performed immunohistochemistry on formalin-fixed, paraffin-embedded specimens using a well-characterized monospecific anti-STS-antiserum [48]. STS protein was predominantly localized in epithelial cells of lobuloalveolar and ductal tissue. However, STS protein staining was also occasionally present in stromal cells (Fig. 1). To quantify STS protein in the breast tissue samples studied, we performed western blots of tissue extracts. A specific band corresponding to the Mr of dimeric STS [51] was detected in all breast tissues investigated (Fig. 2). Interestingly, STS protein expression was significantly increased by approximately $30 \%$ in breast tissue of premenopausal women, resulting in a signal overload (Fig. 2, lanes 6-10).

\subsection{Local $E_{1}$ and $E_{2}$ formation as indicative for $E_{1} S$-sulfatase (STS) activity in vitro}

The activity of STS in kryoconserved normal breast tissue could be demonstrated. The enzyme effectively metabolized the radioactive substrate $E_{1} S . E_{1}$ was the most abundant, labeled estrogen found in breast tissue after incubation with labeled $\mathrm{E}_{1} \mathrm{~S}$. On an average, the concentration of locally formed $E_{1}$ was about 18 (untreated postmenopausal women; $p=0.08$ ) and 53 (untreated premenopausal women; $p \leq 0.05)$ times higher than that of $\mathrm{E}_{2}$. In untreated postmenopausal women, mean $\mathrm{E}_{1}$ and $\mathrm{E}_{2}$ formation was $9.4 \pm 2.9$ and $0.5 \pm 0.2 \mathrm{fmol} /(\mathrm{mg}$ (protein) $\mathrm{min})$, respectively. In contrast, in untreated premenopausal women, mean $\mathrm{E}_{1}$ and $\mathrm{E}_{2}$ formation was $55.5 \pm 16.3$ and $1.0 \pm 0.5 \mathrm{fmol} /(\mathrm{mg}$ (protein) $\mathrm{min})$, respectively. Neither $\mathrm{E}_{1}(p=0.06)$ nor $\mathrm{E}_{2}(p=0.4)$ formation were significantly different comparing pre- and postmenopausal women.

Interestingly, total estrogen formation was decreased after 45 min of incubation when compared to $15 \mathrm{~min}$ of incubation (n.s.).

\subsection{Influence of iCR on $E_{1} S$-sulfatase (STS) activity in vitro}

Both, $E_{1}$ and $E_{2}$ formation after 15 min of incubation were dose-dependently decreased by $\mathrm{iCR}$ treatment compared to controls regardless of menopausal status. However, the reduction of total estrogen formation $\left(E_{1}+E_{2}\right)$ was only significant for iCR treatment at $0.1 \mathrm{mg} / \mathrm{ml}$ in premenopausal women (Figs. 3 and 4). Similarly, after $45 \mathrm{~min}$ of incubation total estrogen formation $\left(E_{1}+E_{2}\right)$ was also significantly decreased by treatment with $\mathrm{iCR}$ at $0.1 \mathrm{mg} / \mathrm{ml}(p \leq 0.05)$ in comparison to controls (Fig. 5). $\mathrm{E}_{1}, \mathrm{E}_{2}$, and total estrogen formation $\left(E_{1}+E_{2}\right)$ after treatment with iCR at $0.1 \mathrm{mg} / \mathrm{ml}$ to $1 \mathrm{ng} / \mathrm{ml}$ did not differ significantly between pre- and postmenopausal women.

Interestingly, the local estrogen formation of one postmenopausal woman was measured in the premenopausal range. This woman had a BMI of 50 suggesting that the higher amount of body and breast fat tissue might have an impact on the local estrogen formation the mammary gland.

\section{Discussion}

To our knowledge we are the first to investigate the effect of iCR on STS activity in normal breast tissue in vitro. Although the amount of epithelial tissue in the mammary gland changes due to age and reproductive stage [52] STS activity has been shown to be present regardless of menopausal stage [53]. We 
(A)

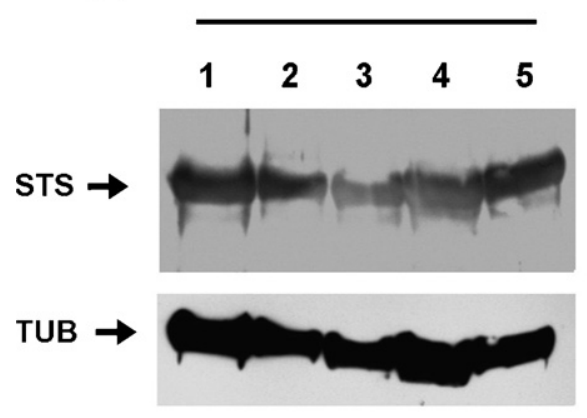

premenopausal

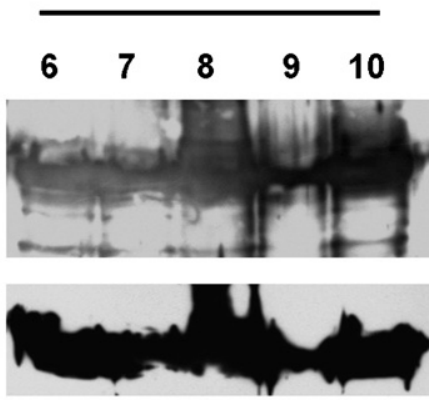

(B)

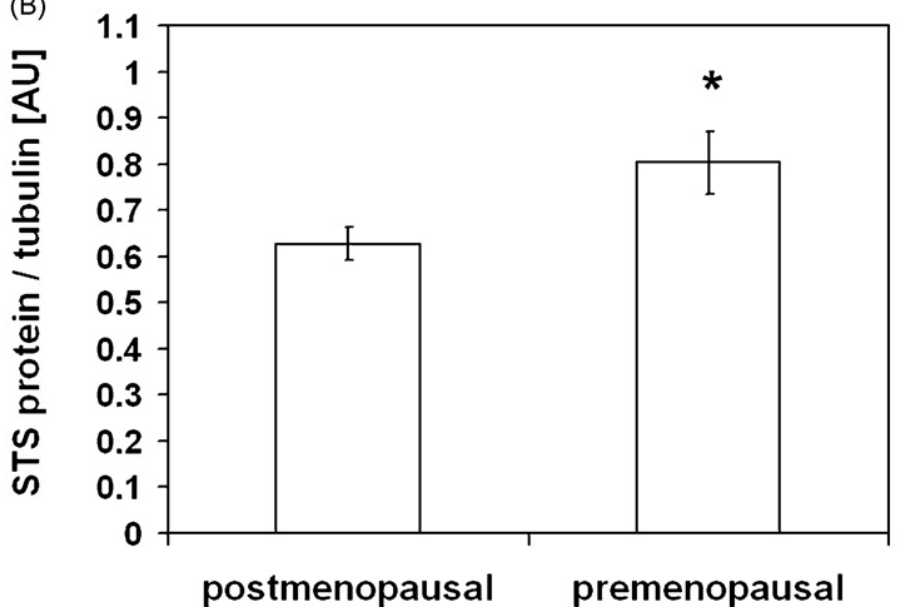

Fig. 2. Western blot analysis of STS protein expression in normal breast tissue from postmenopausal (1-5) and premenopausal (6-10) women. Twenty micrograms protein/lane were subjected to SDS-PAGE and Western blotting using a monospecific STS-antiserum [48]. (A) STS protein expression was detected in all breast tissue samples. High STS protein expression levels in specimens obtained from premenopausal women resulted in a chemoluminescence signal overload (lanes 9-10). (B) Densitometric analysis of STS protein expression normalized for tubulin expression. The signal intensities of the STS and tubulin bands shown in panel A were quantified using NIH image $\mathrm{J}$ software. AU = arbitrary units, ${ }^{*} p>0.05(n=5)$.

demonstrated local estrogen formation being higher in untreated pre- than in postmenopausal breast tissue supporting previous results [53]. Treatment with iCR induced a dose-dependent decrease of both, $E_{1}$ and $\mathrm{E}_{2}$ formation in pre- and postmenopausal breast tissue which was significant at $0.1 \mathrm{mg} / \mathrm{ml}$ in premenopausal breast tissue.

Regarding our enzyme activity assay, we focused on rapid changes in desulfation. After $45 \mathrm{~min}$ of incubation STS activity was not significantly decreased in comparison to $15 \mathrm{~min}$ of incubation. Various $\mathrm{Km}$ for STS activity have been reported by others ranging from 4 to $27 \mu \mathrm{M}$ in human BC tissue [34,35,54-56], 5.8 $\mu \mathrm{M}$ in dysplastic human breast tissue [52], and from 4.1 to
$18.2 \mu \mathrm{M}$ in normal human breast tissue homogenates [57]. $V_{\max }$ for STS activity has been reported to range between 0.8 and $125 \mu \mathrm{mol} \mathrm{E}_{1} /(\mathrm{g}$ (protein) $\mathrm{h})$ in human $\mathrm{BC}$ tissue [35], and between 18.2 and $75.9 \mu \mathrm{mol} \mathrm{E}_{1} / \mathrm{g}$ in normal breast tissue homogenates [57]. Since the substrate concentration in our assay was in the physiological range, no further increase in STS activity was to be expected after $45 \mathrm{~min}$ of incubation, as a steady state of biosynthesis of estrogens had obviously been reached.

Supposing a $100 \%$ bioavailability, the human daily recommended dose, i.e. $50 \mu \mathrm{l} \mathrm{iCR}$, would result in a serum concentration of $1.7 \mu \mathrm{g} / \mathrm{ml}$ [58]. Therefore, the active doses of iCR as present in the tissue homogenate 

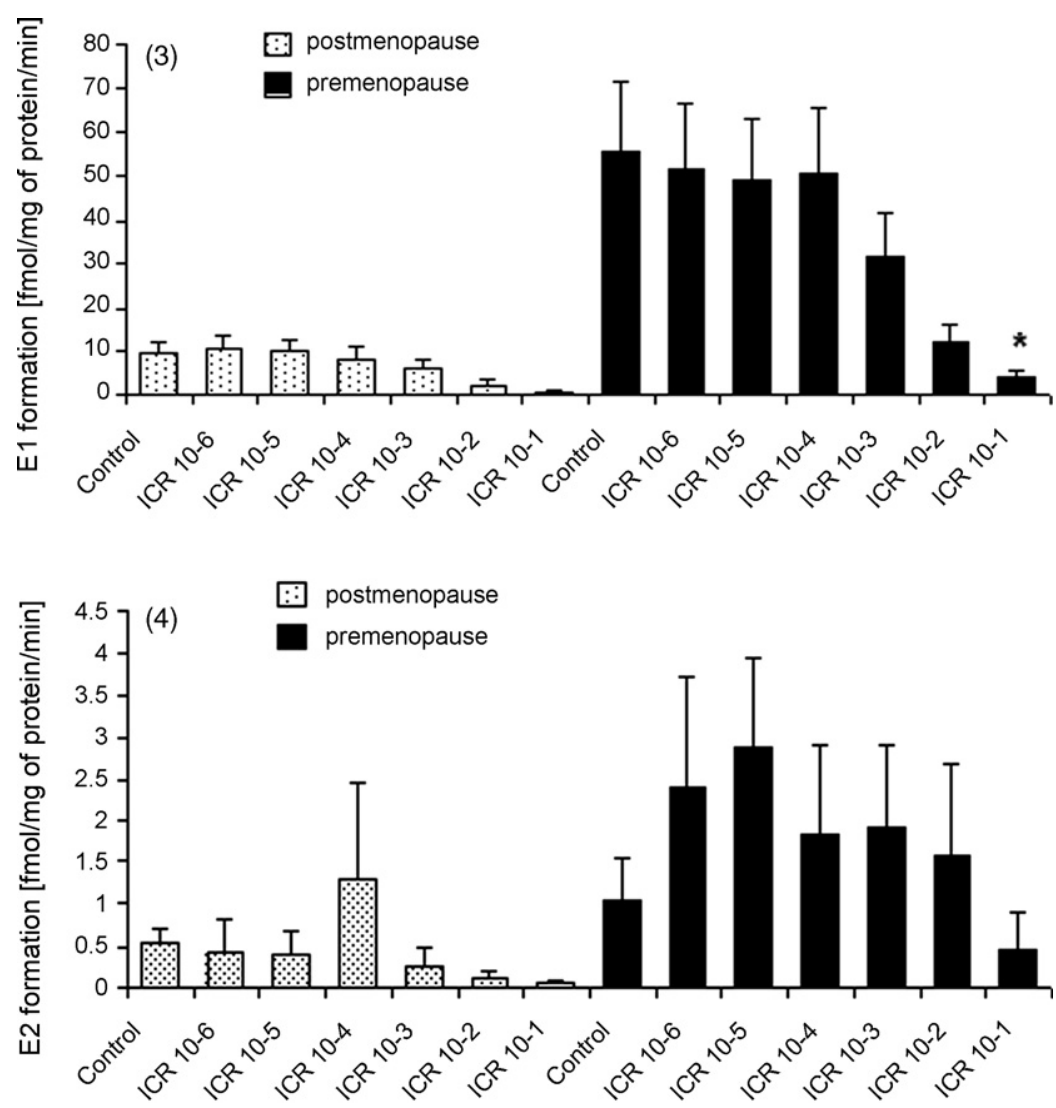

Figs. 3 and 4. $\mathrm{E}_{1}$ S-sulfatase (STS) activity in breast tissue after $15 \mathrm{~min}$ of incubation. Formation of $\mathrm{E}_{1}$ (Fig. 3), and $\mathrm{E}_{2}$ (Fig. 4) is reported. STS activity was evaluated as indicated in the text. Values (in fmol estrogen/( $\mathrm{mg}$ (protein) $\mathrm{min})$ ) are expressed as means and standard error of the mean (S.E.M.). Changes from control are significant for treatment with iCR at $0.1 \mathrm{mg} / \mathrm{ml}$ in premenopausal women. *Significantly different at $p \leq 0.05$. Abbreviations: $\mathrm{E}_{1}=$ estrone; $\mathrm{E}_{2}=$ estradiol; $\mathrm{iCR}=$ isopropanolic extract of Cimicifuga racemosa; $10^{-1}$ to $10^{-6}=\operatorname{concentration}$ at $0.1 \mathrm{mg} / \mathrm{ml}$ to $1 \mathrm{ng} / \mathrm{ml}$.

incubation steps, i.e. 0.1 and $0.01 \mathrm{mg} / \mathrm{ml}$, are well within the range that might be expected locally in certain target tissues.

The decrease of local estrogen formation by iCR could be either a change in the enzyme's amount or its activity. Previous studies in BC cell lines have demonstrated that treatment with estradiol, and various progestins, respectively, rather affect enzyme activity than its protein levels and mRNA expression [40,59]. We previously reported similar effects in nonmalignant human breast cells in vitro [45]. Thus, the enzymatic effects leading to a decreased $E_{1}$ and $E_{2}$ formation could be mediated by a decreased STS, elevated sulfotransferase, or by a shift in the balance of $17 \beta$ HSD type 1 and 2 activity. Progestins have been shown to inhibit the reductive $17 \beta$-HSD activity as well as to stimulate the oxidative $17 \beta$-HSD activity, respectively in $\mathrm{BC}$ cell lines. In contrast, sulfotransferase activity was shown to be increased in MCF-7 and T-47D cell lines when progestins were added [32,41,60,61]. A recent study in $\mathrm{BC}$ cells demonstrated different effects on various enzymes depending on what type of progestin and estradiol was combined with [44]. However, which mechanism is responsible for the effects observed in our study remains to be resolved.

However, in in vivo studies conventional HT, especially estrogen plus progestogen (EPT), has been shown to increase the amount of locally formed estrogens which might at least partly explain the adverse effects on the mammary gland observed by 


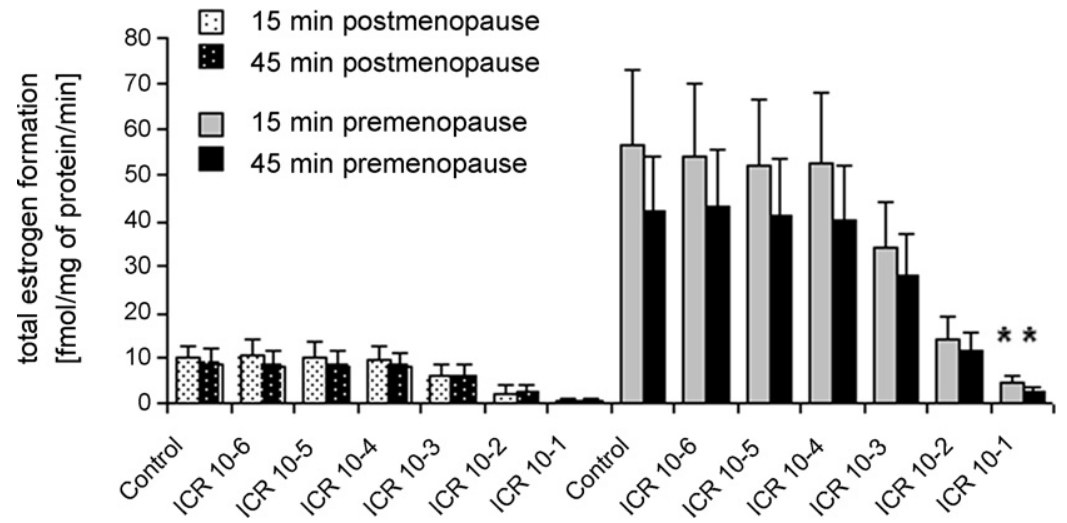

Fig. 5. $E_{1}$ S-sulfatase (STS) activity in breast tissue after 15 and 45 min of incubation. Formation of total estrogen formation $\left(E_{1}+E_{2}\right)$ is reported. STS activity was evaluated as indicated in the text. Values (in fmol estrogen $/(\mathrm{mg}$ (protein) $\mathrm{min})$ ) are expressed as means and standard error of the mean (S.E.M.). Changes from control are significant for treatment with iCR at $0.1 \mathrm{mg} / \mathrm{ml}$ in premenopausal women. *Significantly different at $p \leq 0.05$. Abbreviations: $\mathrm{iCR}=$ isopropanolic extract of $C$. racemosa $; 10^{-1}$ to $10^{-6}=$ concentration at $0.1 \mathrm{mg} / \mathrm{ml}$ to $1 \mathrm{ng} / \mathrm{ml}$.

long-term EPT [46,47]. On the other hand, tibolone, a unique tissue-selective agent for postmenopausal women, has been shown to inhibit tumor growth in the therapeutic rat DMBA induced tumor model and to almost abolish tumor development in the preventive model [43]. One explanation for the breast protective effect is the inhibition of STS activity which was demonstrated for tibolone and its metabolites [42]. Likewise, iCR did not stimulate cancerous growth in the therapeutic rat DMBA induced tumor model either [15]. Furthermore the lack of estrogenity of (isopropanolic and ethanolic extracts of) CR was confirmed by its antiproliferative activity in both, hormone-dependent, and -independent BC cell lines, due to activation of caspases and induction of apoptosis $[11,12]$. Similarly, CR has been shown to induce cell cycle arrest in G1 in MCF-7 and MDA-MB-453 cells [13]. These findings are supported by Lupu et al. reporting no estrogenic activity in RNAse protection assays, estrogen-responsive-element-luciferase assay, the Ishikawa cell system, and in colony formation of ER-expressing breast cancer cells [14]. In healthy postmenopausal women, 6 months of treatment with black cohosh did neither increase mammographic density nor breast cell proliferation [16]. In BC survivors, black cohosh did not lead to an increased but moreover to a slightly decreased risk of $\mathrm{BC}$ recurrence [62]. We suggest, that the lack of estrogenicity and thus the breast protective effects observed might be due to a decrease of locally available active estrogens in breast tissue.
However, future studies investigating long-term effects of $\mathrm{CR}$ on breast tissue should consider menopausal and reproductive stage.

\section{Conclusions}

We conclude that iCR alters local estrogen formation in normal human breast tissue leading to a decrease of local $\mathrm{E}_{1}$ and $\mathrm{E}_{2}$ biosynthesis in vitro. This may explain the lack of estrogenic effects of black cohosh in breast tissue observed in previous studies. Further in vivo studies in normal breast tissue are warranted.

\section{Acknowledgements}

Support: This work was supported by Schaper \& Brümmer GmbH \& Co. KG, 38259 Salzgitter, Germany.

The authors would like to thank W. Lüerßen, M.D. (Department of Plastic Surgery, Centrum Clinic Hohenzollernring, Muenster, Germany), A. KrauseBergmann, M.D. (Department of Plastic Surgery, Fachklinik Hornheide), and J. Tio, M.D. (Department of Obstetrics and Gynecology, University Clinic of Muenster, Germany) for support of this work, and Kurt von Figura, M.D. (University of Göttingen) for the generous gift of the STS-antiserum. We are also grateful to K. Brunswicker, D. Godulla and R. Goez for their outstanding technical contributions to this work. 


\section{References}

[1] McKinney KA, Thompson W. A practical guide to prescribing hormone replacement therapy. Drugs 1998;56:49-57.

[2] Nelson HD, Humphrey LL, Nygren P, Teutsch SM, Allan JD. Postmenopausal hormone replacement therapy: scientific review. JAMA 2002;288:872-81.

[3] North American Menopause Society. Treatment of menopauseassociated vasomotor symptoms: position statement of The North American Menopause Society. Menopause 2004;11(1):11-33.

[4] Collaborative Group on Hormonal Factors in Breast Cancer. Breast cancer and hormone replacement therapy: collaborative reanalysis of data from 51 epidemiological studies of 52,705 women with breast cancer and 108,411 women without breast cancer. Lancet 1997;350:1047-59.

[5] Beral V. Breast cancer and hormone-replacement therapy in the million women study. Lancet 2003;362:419-27.

[6] Chlebowski RT, Hendrix SL, Langer RD, et al. Influence of estrogen plus progestin on breast cancer and mammography in healthy postmenopausal women: the Women's Health Initiative Randomized Trial. J Am Med Assoc 2003;289:3243-53.

[7] Chen WY, Hankinson SE, Schnitt SJ, Rosner BA, Holmes MD, Colditz GA. Association of hormone replacement therapy to estrogen and progesterone receptor status in invasive breast carcinoma. Cancer 2004;101:1490-500.

[8] Writing Group for the Women's Health Initiative Investigators. Risks and benefits of estrogen plus progestin in healthy postmenopausal women: principal results from the women's health initiative randomized controlled, trial. J Am Med Assoc 2002;288:321-33.

[9] Liebermann S. A review of the effetiveness of Cimicifuga racemosa (Black Cohosh) for the symptoms of menopause. J Women's Health 1998;7:525-9.

[10] Liske E. Therapeutic efficacy and safety of Cimicifuga racemosa for gynecologic disorders. Adv Nat Ther 1998;15:45-53.

[11] Hostanska K, Nisslein T, Freudenstein J, Reichling J, Saller R. Cimicifuga racemosa extract inhibits proliferation of estrogen receptor-positive and negative human breast carcinoma cell lines by induction of apoptosis. Breast Cancer Res Treat 2004;84:151-60.

[12] Hostanska K, Nisslein T, Freudenstein J, Reichling J, Saller R. Evaluation of cell death caused by triterpene glycosides and phenolic substances from Cimicifuga racemosa extract in human MCF-7 breast cancer cells. Biol Pharm Bull 2004;27(12):1970-5.

[13] Saxe Einbond L, Shimizu M, Xiao D, et al. Growth inhibitory activity of extracts and purified components of black cohosh on human breast cancer cells. Breast Cancer Res Treat 2004;83:221-31.

[14] Lupu R, Mehmi I, Atlas E, et al. Black cohosh, a menopausal remedy, does not have estrogenic activity and does not promote breast cancer cell growth. Int J Oncol 2003;23(5):1407-12.

[15] Freudenstein J, Dasenbrock C, Nisslein T. Lack of promotion of estrogen-dependent mammary gland tumors in vivo by am isopropanolic Cimicifuga racemosa extract. Cancer Res 2002;62:3448-52.
[16] Linden Hirschberg A, Edlund M, Svane G, Azavedo E, Skoog L, von Schoultz B. An isopropanolic extract of black cohosh does not increase mammographic breast density or breast cell proliferation in postmenopausal women. Menopause 2007;14(1).

[17] Suzuki T, Miki Y, Nakamura Y, et al. Sex steroid-producing enzymes in human breast cancer. Endocr Relat Cancer 2005;12:701-20.

[18] Abul-Hajj YJ, Iverson R, Kiang DT. Aromatization of androgens by human breast cancer. Steroids 1979;33:205-22.

[19] Lipton A, Santner SJ, Santen RJ, et al. Aromatase activity in primary and metastatic human breast cancer. Cancer 1987;59:779-82.

[20] Perel E, Daniilescu D, Kharlip L, Blackstein M, Killinger DW. Steroid modulation of aromatase activity in human cultured breast carcinoma cells. J Steroid Biochem 1988;29:393-9.

[21] Dao TL, Hayes C, Libby PR. Steroid sulfatase activities in human breast tumors. Proc Soc Exp Biol Med 1974;146:381-4.

[22] Vignon F, Terqui M, Westley B, Derocq D, Rochefort H. Effects of plasma estrogen sulfates in mammary cancer cells. Endocrinology 1980;106:1079-86.

[23] Prost O, Turrel MO, Dahan N, Craveur C, Adessi GL. Estrone and dehydroepiandrosterone sulfatase activities and plasma estrone sulfate levels in human breast carcinoma. Cancer Res 1984;44:661-4.

[24] Chapman O, Purohit A, Wang DY, Ghilchik MW, Reed MJ. Oestrone sulphatase activity in normal and malignant breast tissues: relationship with tumour location. Anticancer Res 1995;15:1467-71.

[25] Chetrite GS, Cortes-Prieto J, Philippe JC, Wright F, Pasqualini JR. Comparison of estrogen concentrations, estrone sulfatase and aromatase activities in normal, and in cancerous, human breast tissues. J Steroid Biochem Mol Biol 2000;72:23-7.

[26] MacIndoe JH. The hydrolysis of estrone sulfate and dehydroepiandrosterone sulfate by MCF-7 human breast cancer cells. Endocrinology 1988;123:1281-7.

[27] Pasqualini JR, Chetrite G, Nestour EL. Control and expression of oestrone sulphatase activities in human breast cancer. $\mathrm{J}$ Endocrinol 1996;150(Suppl):S99-105.

[28] Evans TR, Rowlands MG, Law M, Coombes RC. Intratumoral oestrone sulphatase activity as a prognostic marker in human breast carcinoma. Br J Cancer 1994;69:555-61.

[29] Pasqualini JR. Role, control and expression of estrone sulfatase and 17 beta-hydroxysteroid dehydrogenase activities in human breast cancer. Zentralbl Gynakol 1997;119(Suppl 2): 48-53.

[30] Peltoketo H, Isomaa V, Maentausta O, Vihko R. Complete amino acid sequence of human placental 17betahydroxysteroid dehydrogenase deduced from cDNA. FEBS Lett 1998;239:73-7.

[31] Luu-The V, Labrie C, Zhao HF, et al. Characterization of cDNAs for human estradiol 17beta-dehydrogenase and assignment of the gene to chromosome 17: evidence of two mRNA species with distinct $5^{\prime}$-termini in human placenta. Mol Endocrinol 1989;3:1301-9.

[32] Pasqualini JR, Chetrite G, Nguyen BL, et al. Estrone sulfatesulfatase and 17 beta-hydroxysteroid dehydrogenase activities: a hypothesis for their role in the evolution of human breast 
cancer from hormone-dependence to hormone-independence. J Steroid Biochem Mol Biol 1995;53:407-12.

[33] Pasqualini JR, Chetrite G, Blacker C, et al. Concentrations of estrone, estradiol, and estrone sulfate and evaluation of sulfatase and aromatase activities in pre- and postmenopausal breast cancer patients. J Clin Endocrinol Metab 1996;81:1460-4.

[34] Santen RJ, Leszczynski D, Tilson-Mallet N, et al. Enzymatic control of estrogen production in human breast cancer: relative significance of aromatase versus sulfatase pathways. Ann NY Acad Sci 1986;464:126-37.

[35] Santner SJ, Feil PD, Santen RJ. In situ estrogen production via the estrone sulfatase pathway in breast tumors: relative importance versus the aromatase pathway. J Clin Endocrinol Metab 1984;59:29-33.

[36] Utsumi T, Yoshimura N, Takeuchi S, et al. Steroid sulfatase expression is an independent predictor of recurrence in human breast cancer. Cancer Res 1999;59:377-81.

[37] Miyoshi Y, Ando A, Hasegawa S, et al. High expression of steroid sulfatase mRNA predicts poor prognosis in patients with estrogen receptor-positive breast cancer. Clin Cancer Res 2003;9:2288-93.

[38] Pasqualini JR, Chetrite G. Paradoxical effect of estradiol: it can block its own bioformation in human breast cancer cells. J Steroid Biochem Mol Biol 2001;78:21-4.

[39] Pasqualini JR. Differential effects of progestins on breast tissue enzymes. Maturitas 2003;46(Suppl 1):S45-54.

[40] Pasqualini JR, Caubel P, Friedman AJ, Philippe JC, Chetrite GS. Norelgestromin as selective estrogen enzyme modulator in human breast cancer cell lines. Effect on sulfatase activity in comparison to medroxyprogesterone acetate. J Steroid Biochem Mol Biol 2003;84:193-8.

[41] Nguyen BL, Chetrite G, Pasqualini JR. Transformation of estrone and estradiol in hormone-dependent and hormoneindependent human breast cancer cells. Effects of the antiestrogen ICI 164, 384, danazol, and promegestone (R5020). Breast Cancer Res Treat 1995;34:139-46.

[42] Chetrite G, Kloosterboer HJ, Pasqualini JR. Effect of tibolone (ORG OD14) and its metabolites on estrone sulphatase activity in mcf-7 and t-47d mammary cancer cells. Anticancer Res 1997; 17:135-40.

[43] Kloosterboer HJ, Schoonen WG, Deckers GH, Klijn JG. Effects of progestagens and org od14 in in vitro and in vivo tumor models. J Steroid Biochem Mol Biol 1994;49:311-8.

[44] Xu B, Kitawaki J, Koshiba H, et al. Differential effects of progestogens, by type and regimen, on estrogenmetabolizing enzymes in human breast cancer cells. Maturitas 2007;56(2):142-52.

[45] Stute P, Götte M, Kiesel L. Differential effect of hormone therapy on E1S-sulfatase activity in non-malignant and cancerous breast cells in vitro, Breast Cancer Res Treat, 2007, in press.

[46] Stute P, Register TC, Blair R, Cline JM. Effects of tibolone on estrogen biosynthesis in the mammary tissue of postmenopausal monkeys. Menopause 2006;13:232-40.
[47] Stute P, Szuwart T, Schlueter M, Packeisen J, Kiesel L. Effects of hormone therapy on estrogen biosynthesis in the mammary gland of postmenopausal women, submitted for publication.

[48] Stein C, Hille A, Seidel J, et al. Cloning and expression of human steroid-sulfatase. J Biol Chem 1989;264:13865-72.

[49] Bradford MM. A rapid and sensitive method for the quantitation of microgram quantities of protein utilizing the principle of protein-dye binding. Anal Biochem 1976;72:248-54.

[50] Sonntag B, Götte M, Wülfing P, Schüring A, Kiesel L, Greb R. Metformin alters insulin signaling and viability of human granulosa cells. Fertil Steril 2005;84(Suppl 2):1173-9.

[51] Sugawara T, Nomura E, Hoshi N. Both N-terminal and Cterminal regions of steroid sulfatase are important for enzyme activity. J Endocrinol 2006;188:365-74.

[52] Russo J, Russo IH. Molecular basis of breast cancer. Prevention and treatment. 1st ed. Berlin: Springer; 2003.

[53] Söderqvist G, Olsson H, Wilking N, von Schoultz B, Carlstrom K. Metabolism of estrone sulfate by normal breast tissue: influence of menopausal status and oral contraceptives. J Steroid Biochem Mol Biol 1994;48:221-4.

[54] Hawkins RA, Thomson ML, Killen E. Oestrone sulphate, adipose tissue, and breast cancer. Breast Cancer Res Treat 1985;6:75-87.

[55] Tseng L, Mazella J, Lee LY, Stone ML. Estrogen sulfatase and estrogen sulfotransferase in human primary mammary carcinoma. J Steroid Biochem 1983;19:1413-7.

[56] Hobkirk R. Steroid sulfotransferases and steroid sulfate sulfatases: characteristics and biological roles. Can J Biochem Cell Biol 1985;63:1127-44.

[57] Chatterton Jr RT, Geiger AS, Gann PH, Khan SA. Formation of estrone and estradiol from estrone sulfate by normal breast parenchymal tissue. J Steroid Biochem Mol Biol 2003;86:159-66.

[58] Osmers R, Friede M, Liske E, Schnitker J, Freudenstein J, Henneicke-von Zepelin H-H. Efficacy and safety of isopropanolic black cohosh extract for climacteric symptoms. Obstet Gynecol 2005;105:1074-83.

[59] Evans TR, Rowlands MG, Luqmani YA, Chander SK, Coombes RC. Detection of breast cancer-associated estrone sulfatase in breast cancer biopsies and cell lines using polymerase chain reaction. J Steroid Biochem Mol Biol 1993;46:195-201.

[60] Chetrite GS, Kloosterboer HJ, Philippe JC, Pasqualini JR. Effects of Org OD14 (Livial) and its metabolites on 17 betahydroxysteroid dehydrogenase activity in hormone-dependent MCF-7 and T-47D breast cancer cells. Anticancer Res 1999;19:261-7.

[61] Chetrite GS, Pasqualini JR. The selective estrogen enzyme modulator (SEEM) in breast cancer. J Steroid Biochem Mol Biol 2001;76:95-104.

[62] Henneicke-von Zepelin HH, Meden H, Kostev K, SchröderBernhardi D, Stammwitz U, Becher H. Isopropanolic black cohosh extract and recurrence-free survival after breast cancer. Int J Clin Pharmacol Ther 2007;45(3):143-54. 